\title{
TINGKAT KEPUASAN KONSUMEN BERAS PANDANWANGI BERSDASARKAN BENTUK, ORIGINALITAS, MEREK DAN HARGA BERAS (STUDI KASUS DI WILAYAH PEMASARAN BERAS PANDANWANGI DI KABUPATEN CIANJUR)
}

\author{
Oleh: \\ M Yahya Ahmad**) \\ Sherayati Undih Mohammad*)
}

\begin{abstract}
Abstrak
Kabupaten Cianjur merupakan salah satu sentra produksi padi di Provinsi Jawa Barat. Sekitar 96 persen produksi padi dipasok dari lahan sawah irigasi dan sawah tadah hujan dengan menggunakan varietas unggul sedangkan lahan kering yang tersebar di semua Kecamatan belum banyak berkontribusi dalam peningkatan produksi padi.Tujuan penelitian ini adalah untuk mengetahui pengaruh bentuk beras, originalitas, dan merek beras pandanwangi terhadap harga dan kepuasan konsumen. Penelitian ini menggunakan metode analisis jalur dengan Statistical Package For Social Sciance (SPSS) Versi 24. Hasil penelitian ini menunjukkan bahwa variabel bentuk berasmempunyai pengaruh tidak langsung secara signifikan terhadap kepuasan konsumen melalui harga beras dan mempunyai pengaruh langsung terhadap harga. Variabel originalitasdan harga mempunyai pengaruh langsung terhadap variabel kepuasan konsumen, sedangkan variabel lainnya tidak mempunyai pengaruh langsung terhadap harga dan kepuasan konsumen. Variabel yang memiliki pengaruh paling besar adalah harga, hal ini menunjukkan bahwa konsumen memilih beras pandanwangi yang memiliki nilai harga tinggi karena dapat menjamin keaslian dan kualitas beras.
\end{abstract}

Kata Kunci : Pandanwangi, Bentuk, Originalitas, Merek, Harga Beras, Kepuasan Konsumen.

\begin{abstract}
Abstrak
Cianjur Regency is one of the rice production centers in West Java Province. About 96 percent of rice production is supplied from irrigated rice fields and rainfed rice fields by using superior varieties, while the dry land that spread in all sub-districts has not much contributed in increasing the paddy production. The purpose of this study was to determine the effect of the rice shape, originality, and brand of pandanwangi rice on price and customer satisfaction. The research data uses path analysis method of Statistical Package For Social Sciance (SPSS) version 24. The results of this study indicate that rice shape variables has a significant indirect effect on customer satisfaction through rice prices and has a direct influence on prices. Originality and price variables has a direct influence on customer satisfaction, while other variables bas no direct influence on price and customer satisfaction. The variable that has the big influence is price, this indicates that consumers choose pandanwangi rice which has a high price value because it can guarantee the originality and quality of rice.
\end{abstract}

Keywords : Pandanwangi, Shape, Originality, Brand, Price of Rice, Consumer Satisfaction.

*) Alumni Fakultas Sains Terapan UNSUR

**) Dosen Fakultas Sains Terapan UNSUR

TINGKAT KEPUASAN KONSUMEN BERAS

M YAHYA AHMAD dan

PANDANWANGI BERSDASARKAN BENTUK, SHERAYATI UNDIH MOHAMMAD 


\section{PENDAHULUAN}

Jawa Barat memiliki beberapa varietas padi unggul yang bisa menghasilkan beras kualitas premium. Diantaranya adalah beras merah, hitam, dan beras pandanwangi. Beras Pandanwangi Cianjur merupakan salah satu jenis beras kualitas premium dan komoditas unggulan Kabupaten Cianjur.

Kabupaten Cianjur merupakan salah satu sentra produksi padi di Provinsi Jawa Barat. Sekitar 96 persen produksi padi dipasok dari lahan sawah irigasi dan sawah tadah hujan dengan menggunakan varietas unggul sedangkan lahan kering yang tersebar di semua Kecamatan belum banyak berkontribusi dalam peningkatan produksi padi. Produksi padi saat ini dituntut untuk berdaya saing tinggi sehingga harus diawali dengan penggunaan benih bermutu (bersertifikat) (Dinas Pertanian Kabupaten Cianjur, 2007).

Pandanwangi merupakan beras wangi beraroma pandan yaitu beras yang merupakan satu-satunya beras terbaik yang tidak ditemukan di daerah lain dan menjadi khas Cianjur. Beras Pandanwangi memiliki berbagai keunggulan jika dibandingkan dengan beras varietas lain. Ciri-ciri beras itu berbentuk bulat panjang, pada bagian tengah butir-butir beras itu ada titik kapur, bila dicium harumnya terasa wangi khas beras. Beras pandanwangi dapat menghasilkan nasi yang pulen dan memiliki wangi pandan alami. Selain rasanya yang enak harga nyapun relatif lebih tinggi dibanding beras varietas lain.

Salah satu permasalahan yang dihadapi beras pandanwanagi Cianjur yaitu, semua perusahaan beras mengaku bahwa merek produk mereka merupakan Pandanwangi asli. Padahal sebagian besar beras yang beredar di pasar umumnya dicampur dengan beras lain yang lebih murah dan diberi aromatik buatan sehingga menyerupai pandanwangi yang asli.
Berdasarkan permasalahan di atas maka, peneliti tertarik untuk melakukan sebuah penelitian di Kabupaten Cianjur, dengan judul penelitian yaitu "Tingkat Kepuasan Konsumen Beras Pandanwangi Berasarkan Bentuk, Originalitas, Merek dan Harga Beras di Kabupaten Cianjur".

\section{METODE PENELITIAN}

Tempat penelitian ini dilaksanakan di Wilayah Kabupaten Cianjur di beberapa lokasi terutama di tempattempat yang melakukan penjualan beras Pandanwangi. Penelitian dilaksanakan selama 4 bulan yaitu dari bulan Maret sampai dengan bulan Juni pada 2019. Data dan informasi yang dibutuhkan berupa data primer dan data sekunder. Pengumpulan data primer diperoleh dengan cara observasi lansung ke lapangan, memberikan kuesioner langsung kepada responden dan dokumentasi. Sedangkan sampel yang digunakan peneliti berjumlah 85 responden beras pandanwangi yang tidak diketahui jumlahnya.

Analisis data yang digunakan dalam penelitian ini adalah analisis jalur dengan menggunakan Statistical Package For Social Sciance (SPSS).

\section{HASIL PENELITIAN}

\section{Analisis Jalur (Path Analysis)}

Analisis jalur digunakan untuk penentuan variabel bebas yaitu: bentuk, originalitas dan merek beras pandanwangi, mana yang berpengaruh dominan atau yang mempunyai pengaruh signifikan terhadap variabel terikat yaitu kepuasan konsumen, juga dapat menelusuri mekanisme (jalur-jalur) pengaruh bebas (X) terhadap variabel terikat $(\mathrm{Y})$ baik secara langsung maupun tidak langsung. Untuk itu langkah awal dilakukan terlebih dahulu dapat dilakukan analisis regresi.

Pada hasil analisis regresi dapat dilihat dari nilai beta dan signifikan (Sig). Nilai beta yang paling tinggi dan nilai 
signifikan yang paling rendah di bawah 0,005 (sig<0,005), maka faktor tersebut dinyatakan faktor yang paling berpengaruh signifikan atau berpengaruh nyata terhadap variabel $(\mathrm{Y})$ yaitu kepuasan konsumen beras Pandanwangi. Berikut ini merupakan hasil regregsi yang dihutung menggunakan SPSS versi 24 dapat dilihat pada tabel model I dan Model II.

\section{1) Hasil Analisis Jalur Model I}

Model I menggambarkan pengaruh variabel bentuk $\left(\mathrm{X}_{1}\right)$, originalitas $\left(\mathrm{X}_{2}\right)$, dan merek $\left(\mathrm{X}_{3}\right)$ (Independent) terhadap variabel harga $\left(\mathrm{Y}_{1}\right)$ (dependent). Dapat dilihat hasil analisis jalur pada anova.

Tabel 1. Hasil Analisis Jalur pada Korelasi dan Anova

\begin{tabular}{cccccc}
\hline Constant & $\mathbf{R}^{\mathbf{2}}$ & $\mathbf{F}$ & Standard Coefficients (Beta) & $\mathbf{T}$ & Sig \\
\hline X1 & \multirow{2}{*}{0,096} & \multirow{2}{*}{2,883} & 0,311 & 2,645 & 0,010 \\
X2 & & 0,046 & 0,425 & 0,672 \\
X3 & & $-0,020$ & $-0,163$ & 0,871 \\
\hline
\end{tabular}

Besarnya angka $\mathrm{R}$ square $\left(\mathrm{R}^{2}\right)$ adalah 0,096. Artinya pengaruh bentuk, originalitas dan merek terhadap harga adalah $9,6 \%$.

Hipotesis $F_{\text {penelitian }}$ dengan rumus: $\mathrm{df}(\mathrm{n} 1)=\mathrm{k}-1=3-1=2$ $\mathrm{df}(\mathrm{n} 2)=\mathrm{n}-\mathrm{k}=85-3=82$

Dimana dalam penelitian ini $\mathrm{k}$ adalah jumlah variabel bebas sebanyak 3 variabel dan $\mathrm{n}$ adalah jumlah responden/sampel penelitian sebanyak 85 orang.

1. $\mathrm{H}_{0}$ : Tidak ada hubungan linier antara bentuk, originalitas, dan merek dengan harga

2. $\mathrm{H}_{1}$ : Ada hubungan linier antara bentuk, originalitas, dan merek dengan harga.

Pada taraf signifikansi 0,05 (5\%), didapat angka $\mathrm{F}$ penelitian sebesar 2,883 < 3,11 sehingga $\mathrm{H} 1$ ditolak dan $\mathrm{H} 0$ diterima artinya tidak ada hubungan linier antara bentuk, originalitas, dan merek dengan harga.

Hipotesis $\mathrm{T}$ penelitian adalah sebagai berikut:

Terima $\mathrm{H}_{0}$ : Tidak ada pengaruh linier antara variabel bentuk $\left(\mathrm{X}_{1}\right)$, originalitas $\left(\mathrm{X}_{2}\right)$ dan merek $\left(\mathrm{X}_{3}\right)$ beras pandanwangi (independent) dengan harga $\left(\mathrm{Y}_{1}\right)$ beras pandanwangi (dependent).

Tolak $\mathrm{H}_{0}$ : Ada pengaruh linier antara variabel bentuk $\left(\mathrm{X}_{1}\right)$, originalitas $\left(\mathrm{X}_{2}\right)$ dan merek $\left(\mathrm{X}_{3}\right)$ beras pandanwangi (independent) dengan harga $\left(\mathrm{Y}_{1}\right)$ beras pandanwangi (dependent).

Kriteria uji hipotesisnya dapat menggunakan thitung yang dibandingkan dengan $t_{\text {tabel }}$ atau membandingkan dengan nilai signifikansi dengan tarafnya (level of significancy) $=\alpha$.

Jika thitung $>$ tabel $_{\text {taka }}$ tolak $\mathrm{H}_{0}$ atau jika nilai sig $<\alpha$. : Tolak $\mathrm{H}_{0}$

Jika $t_{\text {hitung }}<\mathrm{t}_{\text {tabel }}$ maka terima $\mathrm{H}_{0}$ atau jika nilai sig $>\alpha$ : Terima $\mathrm{H}_{0}$

Taraf signifikansi 0,05 dan degree of freedom (df) dengan ketentuan: $\mathrm{df}=\mathrm{n}-3$, atau $85-3=82$. Dari ketentuan tersebut, diperoleh angka $t_{\text {tabel }}$ sebesar 1,663.

1) Pengaruh Langsung Bentuk $\left(X_{1}\right)$

Terhadap Harga $\left(\mathrm{Y}_{1}\right)$ Beras

\section{Pandanwangi}

Dari hasil perhitungan diperoleh angka thitung sebesar 2,645 $>t_{\text {tabel }}$ sebesar 1,663 sehingga $\mathrm{H}_{0}$ ditolak. Artinya, ada pengaruh linier antara variabel bentuk beras pandanwangi terhadap variabel harga beras pandanwangi. Besarnya pengaruh bentuk beras pandanwangi terhadap harga beras pandanwangi sebesar 0,311 atau signifikansi sebesar $0,010^{*}$ dimana $<\alpha$ dianggap signifikan. 
2) Pengaruh Langsung Originalitas $\left(\mathrm{X}_{2}\right)$ Terhadap Harga $\left(\mathrm{Y}_{1}\right)$ Beras Pandanwangi

Diperoleh angka thitung sebesar 0,425 $\leq t_{\text {tabel }}$ sebesar 1,663 sehingga $\mathrm{H}_{0}$ diterima. Artinya, tidak ada pengaruh linier antara originalitas beras pandanwangi dengan harga beras pandanwangi. Besarnya pengaruh originalitas terhadap harga sebesar 0,046 atau signifikansi sebesar $0,672 \geq \alpha$ dimana dianggap tidak signifikan.

\section{3) Pengaruh Langsung Merek $\left(X_{3}\right)$ Terhadap Harga $\left(\mathrm{Y}_{1}\right)$ Beras Pandanwangi}

Diperoleh angka thitung sebesar $0,163 \leq \mathrm{t}_{\text {tabel }}$ sebesar 1,663 sehingga $\mathrm{H}_{0}$ diterima. Artinya, tidak ada pengaruh linier antara merek beras pandanwangi dengan harga beras pandanwangi. Besarnya pengaruh merek terhadap harga sebesar $-0,020$ atau signifikansi sebesar $0,871 \geq \alpha$ dianggap tidak signifikan.

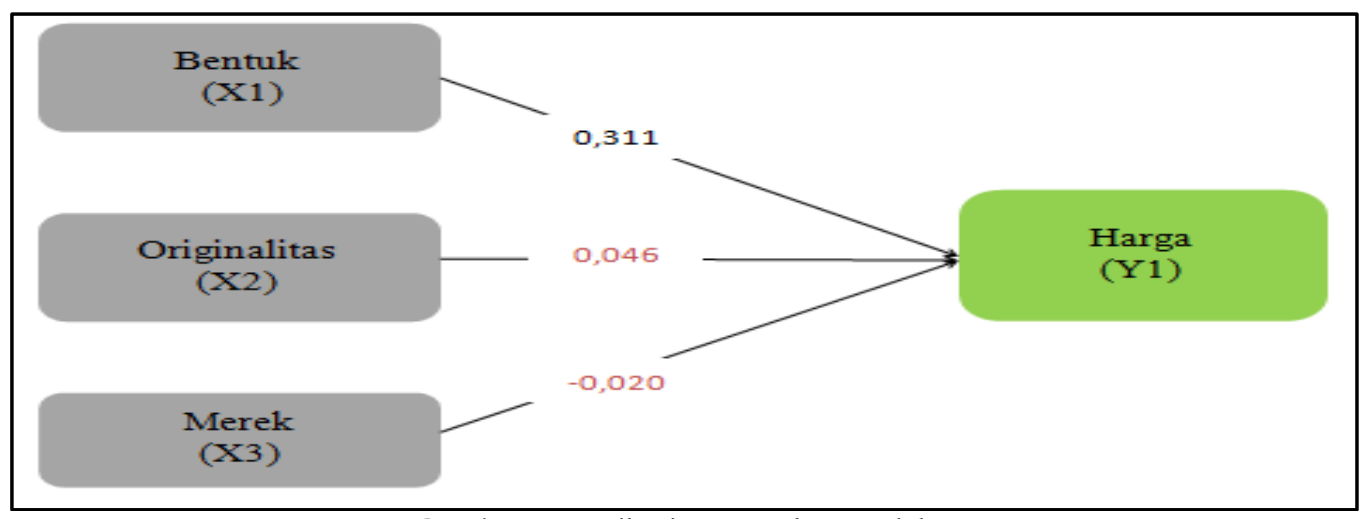

Gambar 1. Hasil Diagram Jalur Model I.

Analisis jalur dalam bentuk persamaan disajikan sebagai berikut:

Keterangan:

$\mathrm{Y}_{1}=0,311 \mathrm{X}_{1}+0,046 \mathrm{X}_{2}+-0,020 \mathrm{X}_{3}+$ error

Harga $=0,0311$ Bentuk $+0,046$

Originalitas + 0,020 Merek + Error
1) Hasil Analisis Jalur Model II

Model II menggambarkan pengaruh variabel Independent bentuk $\left(\mathrm{X}_{1}\right)$, originalitas $\left(\mathrm{X}_{2}\right)$, dan merek $\left(\mathrm{X}_{3}\right)$ (Independent) terhadap variabel harga $\left(\mathrm{Y}_{1}\right)$. Dapat dilihat hasil analisis jalur pada anova.

Tabel 2. Hasil Analisis Jalur Pada Korelasi dan Anova

\begin{tabular}{cccccc}
\hline Constant & $\mathbf{R}^{2}$ & $\mathbf{F}$ & Standard Coefficients (Beta) & $\mathbf{t}$ & Sig \\
\hline X1 & & & $-0,036$ & $-0,323$ & 0,748 \\
X2 & 0,239 & \multirow{2}{*}{, 294} & 0,202 & 2,017 & 0,047 \\
X3 & & & 0,198 & 1,793 & 0,077 \\
Y1 & & & 0,356 & 3,475 & 0,001 \\
\hline
\end{tabular}

Besarnya angka $\mathrm{R}$ square $\left(\mathrm{R}^{2}\right)$ adalah 0,239. Artinya pengaruh bentuk, originalitas, merek, dan harga terhadap kepuasan konsumen adalah $23.9 \%$, sedangkan sisanya $76.1 \%$ dipengaruhi oleh variabel lain yang tidak diteliti.

Hipotesis $F$ penelitian dengan rumus: $\mathrm{df}(\mathrm{n} 1)=\mathrm{k}-1=3-1=2$

$\mathrm{df}(\mathrm{n} 2)=\mathrm{n}-\mathrm{k}=85-3=82$

Dimana dalam penelitian ini $\mathrm{k}$ adalah jumlah variabel bebas sebanyak 3 variabel dan $\mathrm{n}$ adalah jumlah responden/sampel penelitian sebanyak 85 orang.

1. $\mathrm{H}_{0}$ : Tidak ada hubungan linier antara bentuk, originalitas, merek, dan harga dengan kepuasan konsumen.

2. $\mathrm{H}_{1}$ : Ada hubungan linier antara bentuk, originalitas, merek, dan harga dengan kepuasan konsumen. 
Pada taraf signifikansi 0,05 (5\%), didapat angka $\mathrm{F}$ penelitian sebesar 6,294 > 3,11 sehingga $\mathrm{H} 0$ ditolak dan $\mathrm{H} 1$ diterima, artinya ada hubungan linier antara bentuk, originalitas, merek, dan harga dengan kepuasan konsumen.

Hipotesis $\mathrm{T}$ penelitian adalah sebagai berikut:

Terima $\mathrm{H}_{0}$ : Tidak ada pengaruh linier antara variabel bentuk, originalitas, merek, dan harga beras pandanwangi (independent) dengan beras pandanwangi (dependent).

Tolak $\mathrm{H}_{0}$ : Ada pengaruh linier antara variabel bentuk, originalitas, merek, dan harga beras pandanwangi (independent) dengan harga beras pandanwangi (dependent).

Kriteria uji hipotesisnya dapat menggunakan $\mathrm{t}$ hitung yang dibandingkan dengan $t_{\text {tabel }}$ atau membandingkan dengan nilai signifikansi dengan tarafnya (level of significancy) $=\alpha$.

Jika $\mathrm{t}_{\text {hitung }}>\mathrm{t}$ tabel maka tolak $\mathrm{H}_{0}$ atau jika nilai sig $<\alpha$. Tolak $\mathrm{H}_{0}$

Jika $\mathrm{t}$ hitung $<\mathrm{t}$ tabel maka terima $\mathrm{H}_{0}$ atau jika nilai sig $>\alpha$. : terima $\mathrm{H}_{0}$

Taraf signifikansi 0,05 dan degree of freedom (df) dengan ketentuan: $\mathrm{df}=\mathrm{n}-3$, atau $85-3=82$. Dari ketentuan tersebut, diperoleh angka $t$ tabel sebesar 1,663.

1) Pengaruh Langsung Bentuk $\left(X_{1}\right)$

Terhadap Kepuasan Konsumen

$\left(\mathrm{Y}_{2}\right)$ Beras Pandanwangi

Dari hasil perhitungan diperoleh angka thitung sebesar $-0,323 \leq t_{\text {tabel }}$ sebesar 1,663 sehingga $\mathrm{H}_{0}$ diterima. Artinya, tidak ada pengaruh linier antara bentuk beras pandanwangi dengan kepuasan konsumen beras pandanwangi. Besarnya pengaruh bentuk terhadap harga sebesar $-0,036$ atau signifikansi $0,748 \geq \alpha$ dianggap tidak signifikan.

\section{2) Pengaruh Langsung Originalitas}

$\left(\mathrm{X}_{2}\right)$ Terhadap Kepuasan

Konsumen $\left(\mathrm{Y}_{2}\right)$ Beras Pandanwangi

Diperoleh angka thitung sebesar 2,017 $>t_{\text {tabel }}$ sebesar 1,663 sehingga $\mathrm{H}_{0}$ ditolak. Artinya, ada pengaruh linier antara originalitas beras pandanwangi dengan kepuasan konsumen beras pandanwangi. Besarnya pengaruh originalitas terhadap kepuasan konsumen sebesar 0,202 atau signifikansi $0,047 \leq \alpha$ dimana dianggap signifikan.

3) Pengaruh Langsung Merek $\left(X_{3}\right)$ Terhadap Kepuasan Konsumen $\left(\mathrm{Y}_{2}\right)$ Beras Pandanwangi

Diperoleh angka $t_{\text {hitung }}$ sebesar $1,793>t_{\text {tabel }}$ sebesar 1,663 sehingga $H_{0}$ ditolak. Artinya, ada pengaruh linier antara merek beras pandanwangi dengan kepuasan konsumen beras pandanwangi. Besarnya pengaruh merek terhadap kepuasan konsumen sebesar 0,198 atau signifikansi $0,077 \geq \alpha$ dianggap tidak signifikan.

4) Pengaruh Langsung Harga $\left(\mathrm{Y}_{1}\right)$ Terhadap Kepuasan Konsumen $\left(\mathrm{Y}_{2}\right)$ Beras Pandanwangi

Diperoleh angka thitung sebesar 3,475 $>t_{\text {tabel }}$ sebesar 1,663 sehingga $H_{0}$ ditolak. Artinya, ada pengaruh linier antara harga beras pandanwangi dengan kepuasan konsumen beras pandanwangi. Besarnya pengaruh harga terhadap kepuasan konsumen sebesar 0,356 atau signifikansi $0,001 \leq \alpha$ dianggap signifikan. 


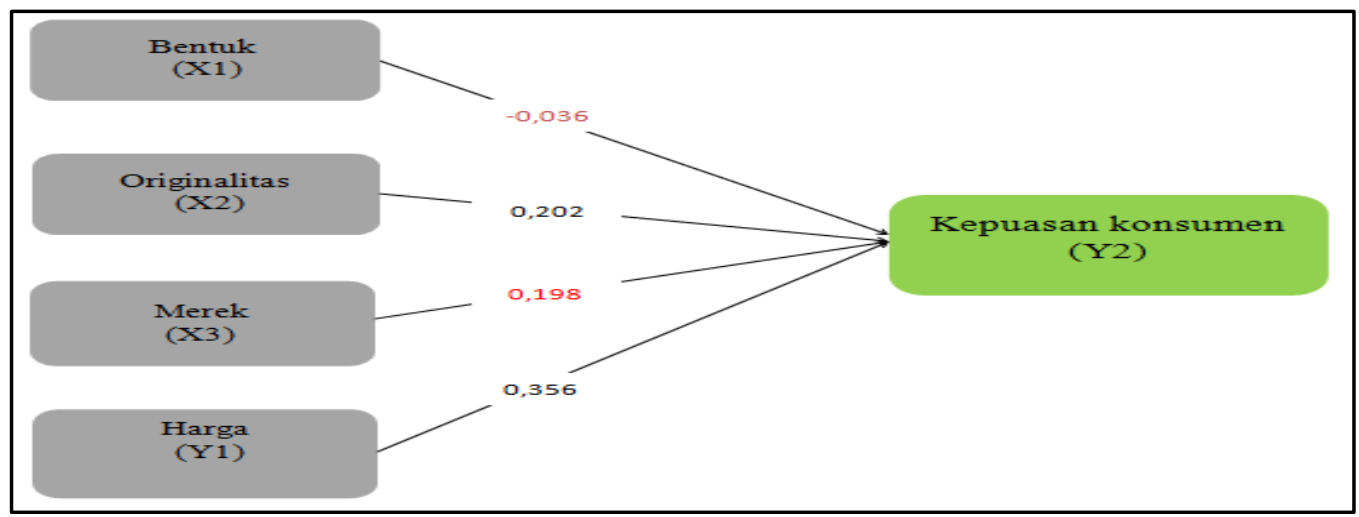

Gambar 2. Hasil Analisis Jalur Model II.

Analisis jalur dalam bentuk persamaan disajikan sebagai berikut:

$\mathrm{Y}_{2}=-0,036 \mathrm{X}_{1}+0,202 \mathrm{X}_{2}+0,198 \mathrm{X}_{3}+$ $0,356 \mathrm{Y}_{1}+$ error atau

Kepuasan Konsumen $=-0,036$ Bentuk + 0,202 Originalitas $+0,198$ Merek $+0,356$ Harga + error.

\section{3) Hasil Analisis Model III}

Adapun hasil penelitian studi kasus tentang beras Pandanwangi di Wilayah pemasaran Kabupaten Cianjur ini sebagai berikut:

1) Hasil Pengaruh Tidak Langsung (Indirect effect) dan Pengaruh Total

a. Pengaruh Tidak Langsung Bentuk $\mathrm{X}_{1}$ melalui Harga $\mathrm{Y}_{1}$ Terhadap Kepuasan Konsumen $\mathrm{Y}_{2}$

Diketahui pengaruh langsung yang diberikan Bentuk $\left(\mathrm{X}_{1}\right)$ terhadap Kepuasan Konsumen $\left(\mathrm{Y}_{2}\right)$ sebesar -0,036. Pengaruh tidak langsung bentuk melalui harga terhadap kepuasan konsumen adalah perkalian antara nilai beta bentuk $\left(\mathrm{X}_{1}\right)$ terhadap harga $\left(\mathrm{Y}_{1}\right)$ dengan nilai beta harga $\left(Y_{1}\right)$ terhadap kepuasan konsumen $\left(\mathrm{Y}_{2}\right)$, yaitu $0,311 \times 0,356=0,110$, sedangkan pengaruh total yang diberikan merek terhadap kepuasan konsumen adalah hasil pengaruh langsung dan pengaruh tidak langsung sebesar $-0,036+$ $0,110=0,146$. Berdasarkan hasil perhitungan nilai pengaruh langsung dan tidak langsung sebesar -0,036 dan pengaruh tidak langsung sebesar 0,110 dimana pengaruh tidak langsung lebih besar dari pengaruh langsung sehingga hasil menunjukkan bahwa merek $\left(\mathrm{X}_{1}\right)$ melalui harga $\left(Y_{1}\right)$ terhadap kepuasan konsumen $\left(\mathrm{Y}_{2}\right)$ mempunyai pengaruh signifikan.

b. Pengaruh Tidak Langsung Originalitas $\left(\mathrm{X}_{2}\right)$ melalui Harga $\left(\mathrm{Y}_{1}\right)$ Terhadap Kepuasan Konsumen ( $\left.\mathrm{Y}_{2}\right)$

Diketahui pengaruh langsung yang diberikan Originalitas $\left(\mathrm{X}_{2}\right)$ terhadap Kepuasan Konsumen ( $\mathrm{Y}_{2}$ ) sebesar 0,202. Pengaruh tidak langsung Originalitas melalui harga terhadap kepuasan konsumen adalah perkalian antara nilai beta Originalitas $\left(\mathrm{X}_{2}\right)$ terhadap harga $\left(\mathrm{Y}_{1}\right)$ dengan nilai beta harga $\left(\mathrm{Y}_{1}\right)$ terhadap kepuasan konsumen $\left(\mathrm{Y}_{2}\right)$, yaitu 0,046 x $0,356=0,016$. Sedangkan pengaruh total yang diberikan originalitas terhadap kepuasan konsumen adalah hasil pengaruh langsung dan pengaruh tidak langsung sebesar $0,202+0,016=0,218$ Berdasarkan hasil perhitungan nilai pengaruh langsung dan tidak langsung sebesar 0,202 dan pengaruh tidak langsung sebesar 0,016 dimana pengaruh langsung lebih besar dari pengaruh tidak langsung sehingga hasil menunjukkan bahwa Originalitas $\left(\mathrm{X}_{2}\right)$ melalui harga $\left(\mathrm{Y}_{1}\right)$ terhadap kepuasan konsumen $\left(\mathrm{Y}_{2}\right)$ tidak mempunyai pengaruh signifikan. 
c. Pengaruh Tidak Langsung Merek $\left(\mathrm{X}_{3}\right)$ melalui harga $\left(\mathrm{Y}_{1}\right)$ Terhadap kepuasan konsumen $\left(\mathrm{Y}_{2}\right)$

Diketahui pengaruh langsung yang diberikan Merek $\left(\mathrm{X}_{3}\right)$ terhadap Kepuasan Konsumen $\left(\mathrm{Y}_{2}\right)$ sebesar 0,198. Pengaruh tidak langsung Originalitas melalui harga terhadap kepuasan konsumen adalah perkalian antara nilai beta Merek $\left(\mathrm{X}_{3}\right)$ terhadap harga $\left(Y_{1}\right)$ dengan nilai beta harga $\left(\mathrm{Y}_{1}\right)$ terhadap kepuasan konsumen $\left(\mathrm{Y}_{2}\right)$, yaitu $-0,020 \times 0,356=0,007$. Sedangkan pengaruh total yang diberikan originalitas terhadap kepuasan konsumen adalah hasil pengaruh langsung dan pengaruh tidak langsung sebesar 0,198 + $0,007=0,205$ Berdasarkan hasil perhitungan nilai pengaruh langsung dan tidak langsung sebesar 0,198 dan pengaruh tidak langsung sebesar 0,007 dimana pengaruh langsung lebih besar dari pengaruh tidak langsung sehingga hasil menunjukkan bahwa Originalitas $\left(\mathrm{X}_{2}\right)$ melalui harga $\left(\mathrm{Y}_{1}\right)$ terhadap kepuasan konsumen $\left(\mathrm{Y}_{2}\right)$ tidak mempunyai pengaruh signifikan.

Tabel 3 Hasil Pengaruh Tidak Langsung Dan Pengaruh Total.

\begin{tabular}{ccc}
\hline Pengaruh Tidak Langsung Melalui & Hasil & Pengaruh Total \\
\hline $\mathrm{X}_{\longrightarrow} \longrightarrow \mathrm{Y}_{1} \longrightarrow \mathrm{Y}_{2}$ & $0,311 \times 0,356=0,110$ & $-0,036+0,110=0,146$ \\
$\mathrm{X}_{1} \longrightarrow \mathrm{Y}_{2} \longrightarrow \mathrm{Y}_{2}$ & $0,046 \times 0,356=0,016$ & $0,202+0,016=0,218$ \\
$\mathrm{X}_{1} \longrightarrow \mathrm{Y}_{1} \longrightarrow \mathrm{Y}_{2}$ & $-0,020 \times 0,356=0,007$ & $0,198+0,007=0,205$ \\
\hline
\end{tabular}

\section{2) Hasil Analisis Model III}

Variabel bentuk $\left(\mathrm{X}_{1}\right)$ memiliki nilai beta terhadap harga $\left(Y_{1}\right)$ sebesar 0,311, sedangkan varaiabel bentuk $\left(\mathrm{X}_{1}\right)$ memiliki nilai terhadap kepuasan konsumen $\left(\mathrm{Y}_{2}\right)$ sebesar -0,036, hasilnya negatif artinya bentuk mempengaruhi harga $\left(\mathrm{Y}_{1}\right)$ karena nilai signikfikansinya lebih kecil dari 0,005 yaitu 0,010, hal tersebut disebabkan semakin bentuknya utuh maka harga pun semakin tinggi. Sedangkan, bentuk $\left(\mathrm{X}_{1}\right)$ tidak mempengaruhi kepuasan konsumen $\left(\mathrm{Y}_{2}\right)$ karena nilai signikfikansinya lebih besar dari 0,005 yaitu 0,748 , hal tersebut dikarenakan konsumen tidak terlalu memperhatikan bentuk beras pandanwangi sehingga bentuk tidak mempengaruhi kepuasan konsumen.

Variabel originalitas $\left(\mathrm{X}_{2}\right)$ memiliki nilai beta terhadap harga $\left(\mathrm{Y}_{1}\right)$ sebesar 0,046 , sedangkan varaiabel originalitas $\left(\mathrm{X}_{2}\right)$ memiliki nilai terhadap kepuasan konsumen $\left(\mathrm{Y}_{2}\right)$ sebesar 0,202, artinya originalitas tidak mempengaruhi harga, karena nilai signikfikansinya lebih besar dari 0,005 yaitu 0,672. Hal tersbut dikarenakan beras pandanwangi termasuk beras khusus sehingga para penjual beras pandanwangi menentukan harga sendiri walaupun beras tersebut kemungkinan besar adalah besar yang tercampur dengan beras varietas lainnya. Kemudian, kurangnya informasi mengenai beras pandanwangi yang asli yang berlogo MP3C sehingga konsumen tidak mengetahui bahwa beras pandanwangi yang asli seperti apa. Originalitas mempengaruhi kepuasan konsumen, karena nilai signikfikansinya lebih kecil dari 0,005 yaitu 0,047 . Hal tersebut dikarenakan beras pandanwangi yang asli memiliki aroma khas dan tekstur yang pulen sehingga konsumen akan merasa puas setelah mengkonsumsi beras pandanwangi yang asli..

Variabel merek $\left(\mathrm{X}_{3}\right)$ memiliki nilai beta terhadap harga $\left(\mathrm{Y}_{1}\right)$ sebesar $-0,020$, sedangkan Variabel merek $\left(\mathrm{X}_{3}\right)$ memiliki nilai terhadap kepuasan konsumen $\left(\mathrm{Y}_{2}\right)$ sebesar 0,198. Artinya merek tidak mempengaruhi harga $\left(\mathrm{Y}_{1}\right)$, dan kepuasan konsumen karena nilai signikfikansinya lebih besar dari 0,005 yaitu 0,871 pada harga dan kepuasan konsumen sebesar 0,077 . Hal tersebut dikarenakan konsumen tidak terlalu memperhatikan merek beras pandanwangi, sedangkan merek itu penting bagi setiap perusahaan karena merek dapat menambahkan imej pada sebuah perusaahaan dan dapat membedakan dengan pesaing lain, oleh karena itu baik konsumen maupun 
produsen perlu mengetahui bahwa beras pandanwangi yang bermerek itu penting.

Variabel Harga $\left(Y_{1}\right)$ memiliki nilai beta terhadap kepuasan konsumen $\left(\mathrm{Y}_{2}\right)$ sebesar 0,356, dan nilai signifikansi kurang dari 0,005 yaitu 0,001 , artinya harga $\left(Y_{1}\right)$ mempengaruhi kepuasan konsumen $\left(\mathrm{Y}_{2}\right)$. Hal tersebut dikarenakan beras pandanwangi termasuk beras khusus sehingga harga tidak ditentukan oleh pemerintah dan harga beras pandanwangi sesuai dengan kualitas dan memiliki rasa yang khas berbeda dengan beras varietas lainnya sehingga konsumen pun akan merasa puas dengan harga beras pandanwangi.

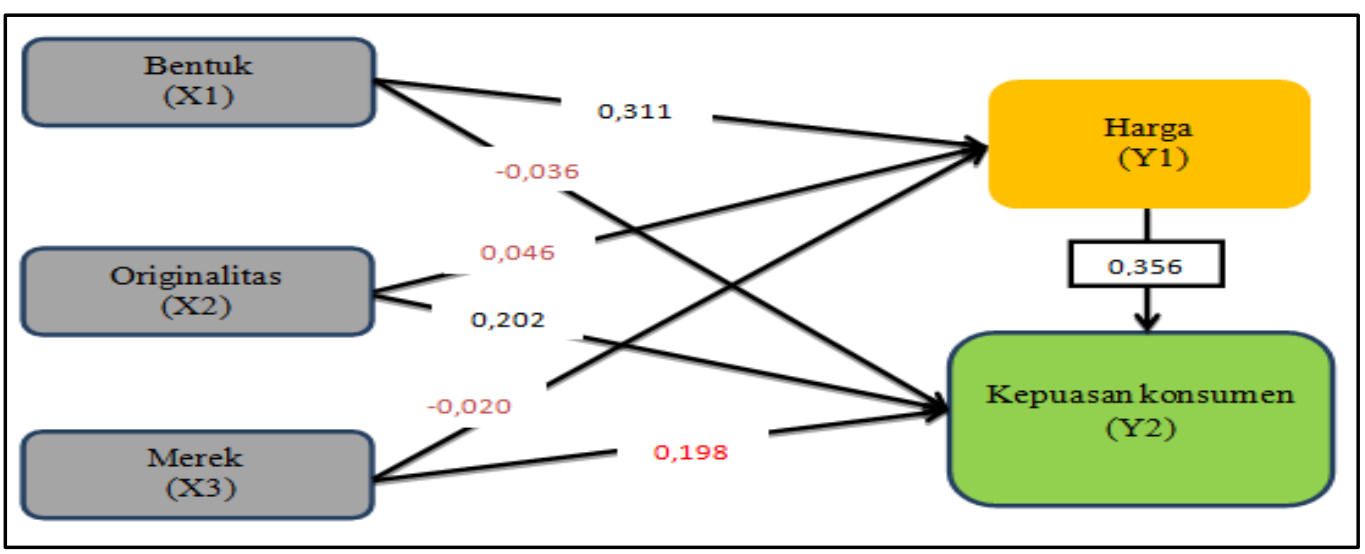

Gambar 3 Hasil Diagram Jalur Gabungan Model I dan Model II.

Dari hasil olahan di atas gambar 4.8 dapat disimpulkan bahwa harga $\left(\mathrm{Y}_{1}\right)$ mendapatkan nilai beta paling besar yaitu 0,356 dan nilai signifikansi kurang dari 0,005 yaitu 0,001 . hal ini menunjukkan bahwa variabel yang berpengaruh signfikan paling besar/dominan terhadap kepuasan konsumen beras pandanwangi $\left(\mathrm{Y}_{2}\right)$ adalah harga $\left(\mathrm{Y}_{1}\right)$. Dimana, hal ini dapat diartikan bahwa harga berpengaruh signfikan terhadap kepuasan konsumen beras pandanwangi di Kabupaten Cianjur.

\section{KESIMPULAN}

Berdasarkan hasil penelitian dan pembahasan yang dilakukan serta hasil analisis jalur untuk mengetahui faktorfaktor yang mempengaruhi langsung maupun secara tidak langsung terhadap kepuasan konsumen beras pandanwangi di Wilayah pemasaran Kabupaten Cianjur, maka dapat ditarik kesimpulan sebagai berikut:

1. Pengaruh langsung variabel bebas (independent) terhadap variabel terikat (dependent). Dapat disimpulkan bahwa variabel bentuk $\left(\mathrm{X}_{1}\right)$ berpengaruh langsung terhadap harga secara sangat signifikan. Hal tersebut dikarenakan jika bentuk beras pandanwangi hampir semua utuh maka harganya pun relatif tinggi. Sedangkan pada variabel originalitas $\left(\mathrm{X}_{2}\right)$ dan merek $\left(\mathrm{X}_{3}\right)$ tidak berpengaruh langsung secara signifikan. Hal tersebut dikarenakan konsumen tidak terlalu memperhatikan beras pandawangi yang asli dan yang bermerek sehingga originalitas dan merek tidak berpengaruh terhadap harga beras.

2. Terdapat pengaruh langsung variabel originalitas $\left(\mathrm{X}_{2}\right)$ dan harga $\left(\mathrm{Y}_{1}\right)$ terhadap kepuasan konsumen $\left(\mathrm{Y}_{2}\right)$ secara signifikan. Hal tersebut karena konsumen akan merasa puas jika beras pandawangi yang dikonsumsinya adalah beras pandawangi asli karena memiliki aroma khas pandan dan rasa yang enak sehinnga konsumen akan merasa puas setelah mengkonsumsi beras pandanwangi yang asli.

3. Variabel bentuk berpengaruh tidak langsung secara signifikan terhadap kepuasan konsumen melalui harga, karena nilai pengaruh tidak langsung 
lebih besar dari nilai pengaruh langsung, sedangkan pada variabel originalitas dan merek tidak berpengaruh secara signifikan karena nilai pengaruh tidak langsung lebih kecil dari pengaruh langsung.

\section{DAFTAR PUSTAKA}

Aldy, Rochmat Purnomo. 2016. Analisis Statistik Ekonomi dan Bisnis Dengan SPSS. Yogyakarta: Fadilatama.

Annissa. 2007. Pengembangan Metode Penentuan Kemurnian Beras Varietas Pandanwangi Berdasarkan Karakterisitik Fisik. Institut Pertanian Bogor. https://repository.ipb.ac.id/bitstrea $\mathrm{m} /$ handle/123456789/48468/F07a nn.pdf? sequence $=1$ \&is Allowed $=\mathrm{y}$ (Diakses pada tanggal 16 Februari 2019 pukul 8:00 wib).

Badan Perencanaan Pembangunan Daerah Provinsi Jawa Barat. 2009. Rencana Tata Ruang Wilayab Provinsi Jawa Barat 2009-2029. Badan Perencanaan Pembangunan Daerah Provinsi Jawa Barat. Bandung.

Basu, Swasta. 2008. Manajemen Pemasaran Modern. Liberty.

Buchari, A. 2011. Manajemen Pemasaran dan Pemasaran Jasa. Alfabeta: Bandung.

Dharmesta dan Irawan. 2008. Manajemen Pemasaran Modern. Liberty: Yogyakarta.

Depkes RI. 2009. Profil Kesehatan Indonesia. Departemen Republik Indonesia: Jakarta.

Dewi, Kasuma Nila. 2012. Pengaruh Iklan, Citra Merek, dan Kepuasan Konsumen Terhadap Loyalitas Konsumen dalam Menggunakan Vaseline Hand and Body Lotion di Kota PADANG. Jurnal Manajemen dan Kewirausahaan. Volume (3): no 2.

http://blog.ub.ac.id/dinaandri/files L2013/03/Jurnal-Manajemen-dan-

Kewirausahaan.pdf (Diakses pada tanggal 16 Februari 2019 pukul 13:00 wib).

Dinas Pertanian Tanaman Pangan Kabupaten Cianjur. 2007. Laporan Tabunan Kabupaten DT II Cianjur: Cianjur.

Fadila, Dewi. 2013. Perilaku Konsumen. Palembang: Citrabooks Indonesia.

Faisal, Risqi M. Lisarini, Endah. 2015. Pengaruh Kualitas dan Harga Beras Pandanwangi Terhadap Kepuasan Konsumen di Wilayah Pemasaran Cianjur.Jurnal Agrosciance. Volume (5): no 2. https://jurnal.unsur.ac.id/agroscien ce/article/viewFile/106/52

(Diakses pada tanggal 12 Februari 2019).

Faisal, Rizki M. 2015. Kualitas Produk dan Harga Terhadap Kepuasan Konsumen Beras Pandawangi di GPO Nyi-Sri Kecamatan Cianjur. Cianjur.

Effendi, M Guntur. 2010. Transformasi Manajemen Pemasaran dan Membangun Citra Negara. Jakarta: Sagung Seto.

Ghozali, Imam. 2013. Aplikasi Analisis Multivariate dengan Program SPSS. Semaran: Universitas Diponegoro.

Hermawan Kertajaya. 2010. Grow with Character: The Model Marketing. Jakarta: PT. Gramedia Pustaka Utama.

Husein, Umar.2005.Metode Penelitian. Jakarta:Salemba Empat.

Kertajaya, Hermawan. 2010. Brand Operation. Jakarta: Esensi Erlangga Group.

Koswara. 2009. Teknologi Pengolahan Berashttp://tekpan.unimus.ac.id/w $\mathrm{p}-$ content/uploads/2013/07/Teknol ogi-Pengolahan-Beras-Teori-danPraktek.pdf(Diakses pada tanggal 12 Februari 2019 pukul 22: 35 wib).

Kotler dan Armstrong. 2008. PrinsipPrinsip Pemasaran. Jilid 1 dan 2. Edisi 12. Jakarta: Erlangga. 
Kotler dan Armstrong. 2013. Prinsip Prinsip Pemasaran. Edisi Ke-12. Jakarta: Erlangga.

Kotler dan Keller. 2012. Manajemen Pemasaran. Edisi 12. Jakarta: Erlangga.

Kotler, Philip. 2001. Manajemen Pemasaran: Analisis Perencanaan Implementasi dan Kontrol. Jakarta: Prehallindo.

Kotler. 2009. Manajemen Pemasaran. Edisi 13. Jakarta: Erlangga.

Kuncoro, Mudrajad. 2003. Metode Riset Untuk Bisnis dan Ekonomi. Jakarta: Erlangga.

Lisarini, Endah. 2017. Kualitas Produk, Komunikasi Pemasaran dan Luaran Saluran Distribusi Pemasaran Beras Pandanwangi Implikasinya Pada Loyalitas Konsumen Di Wilayah Pemasaran Jawa Barat Dan Jakarta. Bandung.

Lupiyoadi. 2001. Manajemen Pemasaran Jasa Teori dan Praktek. Jakarta: Salemba Empat.

Masyarakat Pelestari Padi Pandanwangi Cianjur. 2015. Вuku Persyaratan Permohonan Pendaftaran Indikasi Geografis Beras Pandanwangi Cianjur. Cianjur: MP3C.

Maulida, Nenden. 2018. Tingkat Kesukaan Konsumen Pada Atribut Beras Pandanwangi Murni Cianjur. Cianjur.

Riduwan. 2010. Skala Pengukuran VariabelVariabel Penelitian. Bandung: Alfabeta.

Sarwono, J. 2007. Analisis Jalur Untuk. Riset Bisnis Dengan SPSS. Yogyakarta: Andi.

Schiffman dan Kanuk. 2007. Perilaku Konsumen. Edisi Kedua. Jakarta: PT. Indeks Gramedia.

Solimun. 2007. Multivariate Analysis. Structural Equation Model, Lisrel dan Amos. Universitas Brawijaya. Malang.

Sugiyono. 2005. Metode Penelitian Bisnis. Bandung: Alfabeta.

Sugiyono. 2011. Metode Penelitian Kuantitatif, Kualitatif dan R\&D. Bandung: Alfabeta.
Sugiyono. 2012. Metode Penelitian Kuantitatif Kualitatif dan R\&D. Bandung: Alfabeta.

Sugiyono. 2017. Metode Penelitian Kuantitatif, Kualitatif dan R\&D. Bandung: Alfabeta.

Suryana, A. 2003. Perspektif dan Upaya Pemantapan Peningkatan Pangan Secara Berkelanjutan Prosiding Tekanan Penduduk, Degradasi Lingkungan dan Ketahanan Pangan. Institut Pertanian Bogor: Bogor.

Tarwotjo. 2008. Dasar-Dasar Gizi Kuliner. Jakarta: Grasindo

Tjiptono. 2001. Manajemen Pemasaran dan Analisa Perilaku Konsumen. Yogyakarta: BPFE.

Tjiptono, Fandy. 2011. Manajemen Strategi \& Merek. Yogyajakarta: Andi.

Mulyadi, Yadi. 2018. Keputusan Konsumen Terhadap Pembelian Beras Merah Yang Dipengaruhi Faktor 